\title{
РОССИЯ НА МИРОВОМ РЫНКЕ ТРАНСПОРТНЫХ УСЛУГ: ПРОБЛЕМЫ И ПЕРСПЕКТИВЫ ${ }^{1}$
}

\section{RUSSIA IN THE WORLD MARKET OF TRANSPORT SERVICES: PROBLEMS AND PROSPECTS}

\section{N. Toropova \\ Sh. Guseinov \\ E. Mehdiev}

Summary: The issues discussed in the article are devoted to the integration of the Russian services market into the general structure of the world services market. The paper substantiates the importance of transport services and the prospects for the development of Russian exports of transport services. The article focuses on the general problems of export of Russian services and the place of export of transport services as the main competitive component in the world market of services. The results of the research can be applied in theoretical studies devoted to the development trends of both the global and domestic service markets.

Keywords: export of services, world market of services, transport services, transport corridors, potential, competitive advantages, support mechanisms.
Торопова Наталья Валентиновна

К.э.н., в.н.С., Финансовый университет при Правительстве Российской Федерации NToropova@fa.ru

Гусейнов Шахин Рагим оглы

Д.э.н., Московский государственный институт международных отношений МИД России

9585015@mail.ru

Мехдиев Эльнур Таджаддинович

К.и.н., в.н.С., Финансовый университет при Правительстве Российской Федерации e.mehdiev@gmail.com

Аннотация: Вопросы, рассматриваемые в статье посвящены интеграции российского рынка услуг в общую структуру мирового рынка услуг. В работе обосновывается важность транспортных услуг и перспективы развития российского экспорта транспортных услуг. В статье акцентируется внимание на общих проблемах экспорта российских услуги и место экспорта транспортных услуг, как основной конкурентной составляющей на мировом рынке услуг. Результаты исследования могут применяться в теоретических исследованиях, посвященных тенденции развития как мирового, так и отечественного рынка услуг.

Ключевые слова: экспорт услуг, мировой рынок услуг, транспортные услуги, транспортные коридоры, потенциал, конкурентные преимущества, механизмы поддержки.

стических данных открытых источников информации.

Актуальные вопросы мирового рынка транспортных услуг в части возможности участия России в функционировании рынка транспортных услуг северо-восточной Азии исследованы в работе А.Д. Бордаль [1]; интересная оценка рынка транспортных услуг государств - членов ЕАЭС дана в работе А.Ф Завгороднего [2]; вопросам целесообразности развития транспортной системы посредством формирования транспортно-логистических кластеров, развития инфраструктуры и внедрения новых технологий посвящено исследование Д.И. Ткаченко [3]; достаточно подробный анализ содержания и форм экспорта транспортных услуг проведен в исследовании К.В. Холопова и О.В. Соколовой [4].

Характеризуя тенденции мирового экспорта транспортных услуг необходимо заметить, что наибольшее значение, более половины объема от общего количечастности рынка транспортных услуг, а также на статиоснованы на анализе научных трудов отечественных и зарубежных ученых, посвященных проблемам мирового рынка услуг, исследованию отраслевых рынков услуг, в

1 Статья подготовлена в рамках выполнения Государственного задания 2020 г. по теме: «Повышение конкурентоспособности российских услуг на глобальных рынках и формирование в Российской Федерации привлекательных условий для экспортеров услуг и инвесторов». 
ства транспортных услуг, занимают услуги по транспортировке грузов, остальной объем распределяется между сопутствующими/вспомогательными услугами, например: упаковка, обработка, хранение и дополнительные операции необходимые для перевозки грузов, что занимает еще почти четверть объема. Остальная часть объема транспортных услуг распределяется между услугами пассажирских перевозок, почтовых и курьерских услуг.

К крупнейшим экспортерам транспортных услуг относятся страны ЕС, США, Республика Сингапур, Китай/ Гонконг, ОАЭ и Япония.

Политика большинства как экономически развитых, так и развивающихся стран направлена на повышение конкурентоспособности отечественных транспортных операторов на международных рынках, содействие по совершенствованию дорожных сетей, развитие транспортных коридоров, формирование сети транспортнологистических центров, и на пролонгацию интересов в двусторонних и многосторонних переговорах в области транспортных услуг. Продвижению на мировой рынок услуг способствуют принятые в России нормативные документы: в 2017 году Постановление Правительства РФ от 20.12.2017 N 1596 «Об утверждении государственной программы Российской Федерации Развитие транспортной системы» и в ее составе Структура государственной программы Российской Федерации «Развитие транспортной системы» на 2019 - 2024 г. дают четкие стратегические цели и направления, где в качестве основной задачи обозначен: «Рост объемов экспорта транспортных услуг должен быть основан на повышении конкурентоспособности российских транспортных операторов, а также на обеспечении их доступа на зарубежные рынки, в том числе к перевозкам между третьими странами, как транзитом через территорию Российской Федерации, так и минуя ее». Кроме того в Распоряжении Правительства РФ от 14.08.2019 N 1797-р (ред. от 20.06.2020) «Об утверждении Стратегии развития экспорта услуг до 2025 года» (вместе с «Планом мероприятий по реализации Стратегии развития экспорта услуг до 2025 года», в качестве первого раздела изложена стратегия развития транспортных услуг с акцентом на основные направления и перспективы развития мирового рынка транспортных услуг, проблемы и барьеры для развития российского экспорта транспортных услуг, основные задачи и меры по развитию экспорта транспортных услуг.

Учитывая геополитическое расположение России, резонным является вопрос о необходимости развития транспортных услуг, в том числе, и по транспортно-транзитному потенциалу путем развития международных транспортных коридоров. Для решения этой задачи Минтранс создал автономную некоммерческую организацию «Дирекция международных транспортных коридоров» (ДМТК), которая поможет координировать действия с другими ведомствами по развитию проходящих по территории России международных транспортных коридоров.

В настоящее время введены в действие и развиваются крупномасштабные инфраструктурные проекты, способствующие увеличению объемов торговли услуги международного транзита, такие, как:

Транспортные коридоры Программы ЦАРЭС (Центральноазиатское региональное экономическое сотрудничество), стратегия этой программы направлена на улучшение мультимодальной транспортной инфраструктуры в регионе, что приведет к ускорению социально-экономического развития в следующем десятилетии. В марте 2020 года ЦАРЭС опубликовала свою Транспортную стратегию, рассчитанную на период до 2030 года, где предусматривается строительство, реконструкция, модернизация и обслуживание инфраструктуры, развитие станций и интермодальных (связанных с использованием различных видов транспорта в рамках одной поездки) объектов. В этой связи, необходимо предусмотреть разработку программ консолидации российских интересов с принятой Транспортной стратегией, так, чтобы осуществляемые реформы проходили в рамках взаимовыгодных экономических интересов без постоянных вмешательств на уровне политики.

Международные автомобильные коридоры Шанхайской организации сотрудничества в целях расширения торгово-логистического сотрудничества в рамках ШОС, совместное строительство международных логистических и транспортных коридоров между Азией и Европой. Так, летом 2020 года было заявлено о планах по строительству «Нового азиатско-европейского трансконтинентального коридора» протяженностью более 10 тыс. километров, который пройдет из Китая через Центральную Азию и Россию до Нидерландов. Для российской стороны важными решениями станут меры по развитию инфраструктуры и мультимодальных логистических центров, обеспечивающих стыковку различных видов транспорта, проведение модернизации транспортных объектов и унификация стандартов в сфере транспорта.

Программа международного сотрудничества в области транспорта между ЕС и странами-партнерами в Восточной Европе, на Южном Кавказе и в Центральной Азии - Европа-Кавказ-Азия (TPACЕКА). На сегодняшний день страны-участницы ТРАСЕКА поэтапно осуществляют реализацию программы Стратегия МПК ТРАСЕКА 2016-2026 гг. (Стратегия Межправительственной комиссии на 2016-2026 годы по формированию международного транспортного коридора Европа-Кавказ-Азия), где основной акцент делается на создание устойчивой инфраструктурной цепи мультимодальных перевозок с постепенной интеграцией коридора в Трансъевропейские транспортные сети. При наличии единого договора поддерживающего процедуры международных перевозок 
через регион и при наличии унифицированных требований, позволит участникам не только уменьшить временной интервал предоставления услуги транспортировки, но и значительно сэкономить финансовые расходы.

4. Международный транспортный коридор «Север - Юг», инициированный в 2000 году для развития стратегического партнерства России со странами Прикаспийского региона, соглашение о котором было подписано между Россией, Ираном и Индией, а в мае 2002 года был подписан протокол об официальном открытии коридора. Транспортный коридор, связывающий СанктПетербург с портом Мумбаи (Бомбей) протяженностью 7200 км представляет собой мультимодальный маршрут и предназначен для привлечения транзитных грузопотоков в российско-индийско-иранском направлении, через страны Персидского залива, далее через Каспийское море в Северную и Западную Европу. В последствии к инициативе присоединились Азербайджан, Армения, Беларусь, Казахстан, Оман, Сирия. 25 февраля 2020 года между мультимодальным логистическим оператором «РЖД Логистика» (Россия) и оператором железнодорожных контейнерных перевозок CONCOR (Container Corporation of India Ltd) (Индия) подписано соглашение об организации и развития перевозок по международному транспортному коридору (МТК) «Север-Юг». Однако существующие разногласия между странами участницами требуют основательных мер по реализации механизмов признания результатов таможенных процедур на взаимной основе, кроме того до настоящего времени не существует единого электронного документооборота, не согласованы тарифы, кроме того сказывается отсутствие единого оператора. При решении данного вида разногласий потенциал коридора весьма оптимистичен, по прогнозируемым данным ожидается, что к 2025 году по «Северу-Югу» пройдет 3,5 млн тонн грузов, к 2029 году - 8 млн тонн, а к 2050 ежегодный планируемый объём превысит 20 млн тонн грузов.

Нельзя не отметить ситуацию в мире, которая сложилась из-за пандемии коронавируса. Ограничительные меры, принятые на государственных уровнях, направленные на предотвращение распространения пандемических вспышек, привели к существенному снижению экономической активности, что в первую очередь сказалось на транспортных услугах.

Исследование Всемирной организации автомобильного транспорта (IRU) подтвердило, что более 3,5 миллионов автотранспортных операторов во всем мире понесли серьезные финансовые потери в результате транспортных ограничений и общего экономического спада, вызванного пандемией. Проанализируем некоторые данные этого исследования: компании, занимающиеся грузовыми перевозками, ожидают снижения оборота в 2020 году в среднем на 18\% до 551 миллиарда евро; сектор транспортных услуг значительно пострадал на Ближнем Востоке и в Северной Африке (-22\%) и в Азии (-21\%); в Европе - на 64 млрд евро (-17\%); компании в Аргентине, Китае и Иране столкнулись со спадом более чем на 30\%; пассажирские транспортные компании ожидают в этом году потерю 81 миллиарда евро, или 57\% их годового дохода; компании в Болгарии, Испании, Швеции и Великобритании столкнулись со спадом более чем на $70 \%$.

По данным Счетной палаты РФ по итогам 2020 года потери российских транспортных компаний составят 230 млрд руб. По данным Росстат наиболее неутешительный прогноз по самому технологичному сегменту рынка - перевозка проектных и негабаритных грузов. Снижение объемов инвестиций, нарушения цепочек поставок вследствие карантинных мер, девальвация валюты, ограничения на работу в портах по всему миру и многие другие факторы отрицательно влияют на автомобильные перевозки КТГ в 2020 г. Их объем в стоимостном выражении сократился почти на 12\% в 2020 г., при этом возобновление роста ожидается только после 2021 года.

По результатам обсуждения можно сделать выводы, что международная торговля услугами и глобальные производственные сети в значительной степени зависят от бесперебойного функционирования транспортных сетей, и в период, когда мир столкнулся с пандемией коронавируса, операции по предоставлению транспортно-логистических услуг дают сбои. Кроме резкого сокращения спроса, возникают новые нормативные ограничения из-за распространения пандемии, которые нарушают налаженные взаимосвязанные цепочки поставок. В этой ситуации необходимы новые гибкие меры и нормативные документы, обеспечивающие непрерывность транспортно-логистических услуг и гарантирующие защиту цепочек поставок от двойных воздействий ограничительных мер, а кроме того дополнительные усилия, предупреждающие трансформацию временных ограничительных мер в постоянные барьеры и ограничения не сбиваясь в политику протекционизма. Поддерживая меры государственной поддержки, необходимо скорейшее завершение формирования единой цифровой платформы транспортного комплекса, которая бы объединила информационные и цифровые результаты на основе согласованных стандартов, правил и принципов, а также реформировать информационно-справочную систему, предоставляющую сведения о пропускной способности и состоянии загруженности пунктов пропуска, что обеспечит перевозчиков и грузоотправителей актуальной информацией. Что должно привести к увеличению объемов и качества экспорта услуг, повышению конкурентоспособности российских транспортных компаний, а также, способствовать снижению отрицательного сальдо внешнеторгового баланса услуг России. 


\section{ЛИТЕРАТУРА}

1. Бардаль А.Б. Возможности участия России в функционировании рынка транспортных услуг северо-восточной Азии. /В сборнике: большая Евразия: развитие, безопасность, сотрудничество. ежегодник. 2019. С. 13-16.

2. Завгородний А.Ф. К вопросу о рынке транспортных услуг государств - членов ЕАЭС // Ученые записки Санкт-Петербургского имени В.Б. Бобкова филиала Российской таможенной академии. 2019. № 4 (72). С. 48-53.

3. Ткаченко Д.И. Перспективы развития экспорта транспортно-логистических услуг России//Вестник университета. 2020. № 7. С. 83-88.

4. Федоренко Р.В. Проблемы развития таможенно-логистической инфраструктуры международного транспортного коридора «Восток - Запад» // Вестник Российского университета дружбы народов. Серия: Экономика. 2020. Т. 28. № 3. С. 491-504. http://dx.doi.org/10.22363/2313-2329-2020-28-3-491-504

5. Холопов К.В., Соколова О.В. Современное содержание и формы экспорта транспортных услуг //Холопов К.В., Соколова 0.В./ Российский внешнеэкономический вестник. 2018. № 2. С. 25-35.

6. Янг Тэ Ким Транспорт перед лицом пандемии/ Международный Транспортный Форум / $0 Э С$ Р 2020 [электронный pecypc] https://www.itf-oecd.org/ transport-face-pandemic/

7. Микрина В.Г. История возникновения и особенности развития трудовых прав человека // Евразийский юридический журнал. 2019 (129). № 2. С. $205-207$.

8. Ivanov D. Predicting the impacts of epidemic outbreaks on global supply chains: A simulation-based analysis on the coronavirus outbreak (COVID-19/SARSCoV-2) case. Transportation Research Interdisciplinary Perspectives Volume 136, April 2020, $101922 \mathrm{https}$ ://www.sciencedirect.com/science/article/pii/ S1366554520304300

(c) Торопова Наталья Валентиновна (NToropova@fa.ru), Гусейнов Шахин Рагим оглы (9585015@mail.ru),

Мехдиев Эльнур Таджаддинович (e.mehdiev@gmail.com).

Журнал «Современная наука: актуальные проблемы теории и практики»

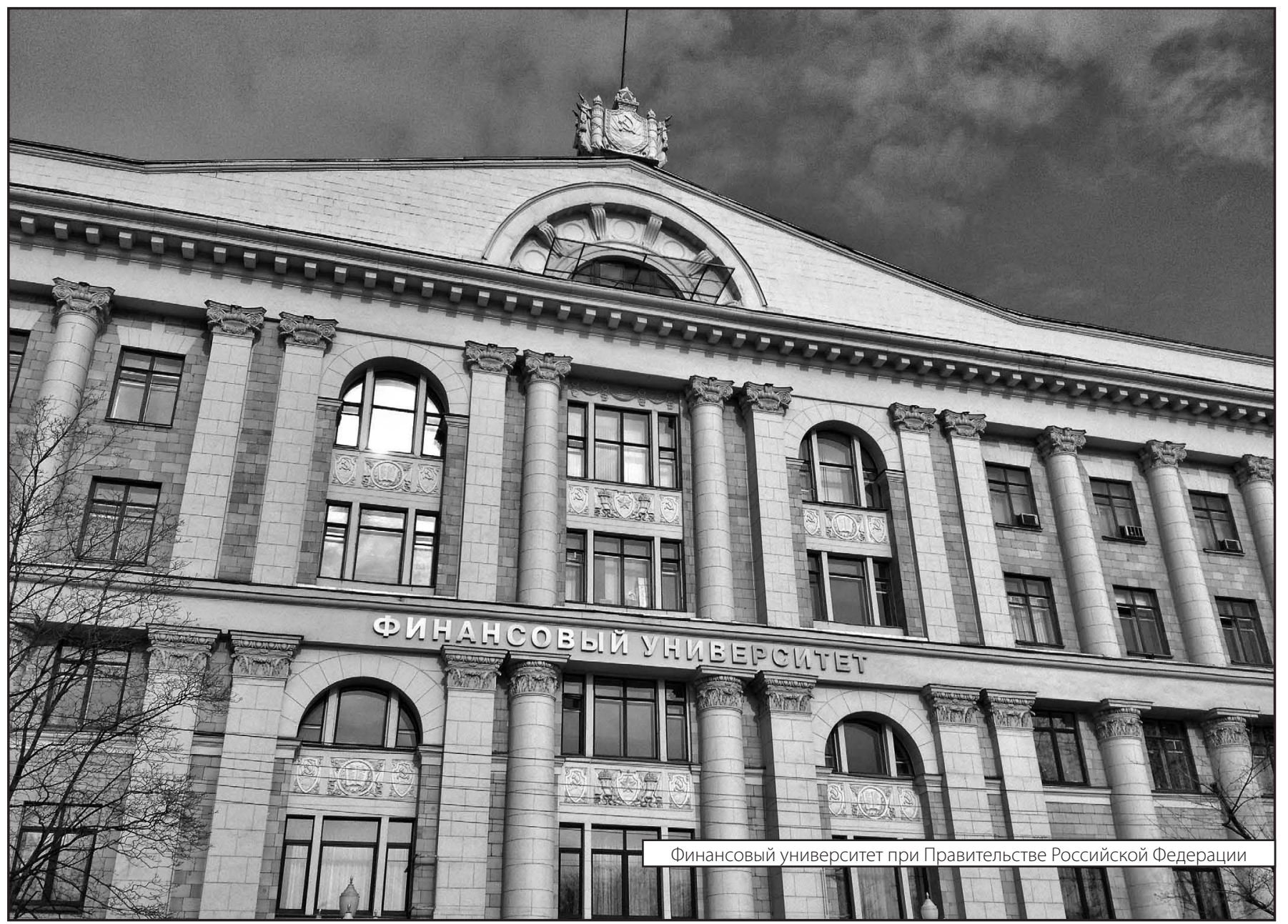

